\title{
Caminando hacia la erradicación de la esclavitud del siglo XXI
}

\author{
TANia García SEdano \\ Doctora en Derecho \\ Magistrada Suplente Audiencia Provincial de Madrid \\ Profesora Asociada de la Universidad Carlos III de Madrid \\ Colaboradora de la Universidad Pontificia de Comillas
}

Recibido: 26/03/2020

Aceptado: $27 / 03 / 2020$

doi: https://doi.org/10.20318/femeris.2020.5394

\section{Introducción}

El pasado seis de marzo se celebró en Getafe, en el espacio Mercado, el día de la mujer y se hizo bajo con una Jornada titulada: Prostitución y trata; la esclavitud del s. XXI que fue organizada por la Delegación de la Mujer e Igualdad del Ayuntamiento y el Instituto de Estudios de Género de la Universidad Carlos III.

La Relatora Especial de Naciones Unidas sobre Formas Contemporáneas de Esclavitud, incluidas sus causas y consecuencias, estima que actualmente en el mundo existen 27 millones de personas que son víctimas de alguna de las formas contemporáneas de esclavitud, entre las que se incluyen el trabajo forzoso y la servidumbre.

La Jornada se incardina dentro de la estrategia que el consistorio municipal está desarrollando para la abolición de la prostitución. Dentro de la misma se celebraron las Jornadas del 8 de marzo bajo el lema "Rebélate", pretendiendo hacer un llamamiento a la necesidad de conquistar derechos y oportunidades para las mujeres y por la abolición de la trata, los vientres de alquiler y la prostitución porque no son oficios, si no la mayor explotación que sufren las mujeres y uno de los negocios más lucrativos del mundo.

Dentro de la Estrategia debe destacarse la aprobación de la Ordenanza de fecha 20 de agosto de 2019, rubricada Ordenanza de convivencia ciudadana del municipio de Ge- 
tafe, y que en palabras de la alcaldesa, Sara Hernández, es: "una ordenanza que nos pone a la altura de otras grandes ciudades que ya la tienen, el objetivo es ordenar en positivo la convivencia, proteger los diferentes usos de nuestra ciudad, para disfrutarla, desde el respeto por los demás y por nuestro entorno".

Es de destacar que Ordenanza tiene como objetivo luchar contra la prostitución, preservando los espacios públicos como lugares de convivencia, civismo e igualdad, evitando actividades de explotación sexual que difundan una imagen del ser humano como mero objeto sexual y perturben la convivencia social.

\section{Análisis de la jornada}

La inauguración de la Jornada corrió a cargo de la Alcaldesa de Getafe, Sara Hernández, y de la Directora del Instituto de Estudios de Género, Rosa San Segundo. Ambas pusieron de manifiesto su compromiso abolicionista y subrayaron que la trata con fines de explotación sexual y la prostitución son un ataque frontal a la dignidad del ser humano.

El acto se estructuró en torno a una ponencia marco, titulada Prostitución, Abolicionismo y feminismo, en la que Rosa Cobo, con su talante didáctico y gran contundencia, defendió el abolicionismo como eje de la cuarta ola feminista e identificó la prostitución como espacio simbólico y real en el que el capitalismo global y el patriarcado priman el beneficio económico a los derechos humanos de las mujeres.

El primer coloquio se articuló entorno a la idea de la construcción de alternativas al discurso hegemónico tendente a la articulación del cuerpo de la mujer como objeto de consumo. En él participaron Olmo Morales Maite Parejo y Eva Martínez Ambite y moderó Rosa San Segundo.

En esta mesa se cuestionó la imagen que de las mujeres existe en los medios de comunicación y redes sociales. No carece de simbolismo ni de propósito, el dibujar y perfilar a las mujeres como un trofeo carente de voluntad, un cuerpo a doblegar o un mero icono de moda.

Se subrayó la relevancia de los grupos de hombres para la construcción de una masculinidad igualitaria y el papel activo de las mujeres en el diseño de una nueva construcción social.

El segundo coloquio giró sobre la proyección del documental Irioweinasi, el hilo de la luna, que narra la historia de Blessing una joven nigeriana en cuya historia de vida encuentran baldosas comunes los diversos relatos de las jóvenes que desde el país africano conocido como el gran elefante negro (por sus riquezas petrolíferas) realizan su proyecto migratorio vinculándose a una red de trata de personas, principalmente con fines de explotación sexual en Europa. El significado de Irioweneiasi es que nadie es tan fuerte como para tirar del hilo de la luna y bajarla, nadie puede arrebatar la vida de un ser que es cuidado, y encierra un contenido profundo que se muestra con lenguaje e imágenes de gran sencillez, sin sentimentalismos, pero con la honestidad y humanidad necesarias para apreciar el verdadero alcance de la realidad vivida por cientos de mujeres. 
El camino por el que atraviesa media África lo realiza por tierra, como ocurre en la mayoría de los casos, habiendo invertido en él algo más de tres años, durante los cuales acumulará daños, estrategias y fuerza.

En una trenza coral se encuentran en esta película las voces de las profesionales que abordan la trata de personas y las de las protagonistas que de alguna manera están vinculadas a ella y que gracias a un proceso de recuperación de su relato a través del arte nos hablan, nos compelen, exigen y proponen.

Con posterioridad a esta proyección y con la tensión contenida debido a la crudeza del fenómeno y a la delicadeza en su abordaje, se abrió un debate, con la participación de las Directoras, Inmaculada Antolínez y Esperanza Jorge, y de las entidades especializadas en materia de trata de seres humanos que actúan en el ámbito getafense: Amar Dragoste y Apramp, que fue moderado por Marian Blanco.

Finalizó la jornada con la última de las mesas en la que se abordaron los retos en la persecución de la trata y abolición de la prostitución: desde la mirada feminista, legislativa y de políticas públicas. En ella se contó con la participación de Montserrat Sampere, Sonia Vivas, Pilar Rasillo y Tania García, moderando el magnífico Juan José Tamayo.

Consideramos que fue un éxito, no solo por la gran asistencia de público si no por su magnífica participación y las sinergias que nacieron en el Acto.

\section{Conclusiones}

Es preciso abordar las causas subyacentes a la trata de seres humanos para poner fin a esta lacra.

No puede prescindirse del enfoque de derechos humanos y de género en el abordaje y debe incorporarse la perspectiva financiera pues ambos fenómenos existen porque son muy lucrativos.

Todos somos agentes clave para acabar terminar con estas realidades tanto como ciudadanos, como consumidores, clientes, etc...

Todos somos agentes clave para acabar terminar con estas realidades, desde la reflexión y desde una perspectiva crítica, tanto como ciudadanos y como consumidores, especialmente aquellos que son los clientes de la prostitución y alientan una de las principales causas de este fenómeno: la demanda.

Los avances en el ámbito local son muy relevantes porque ademas de impactar más directamente sobre su población, dan pautas en contextos más amplios e inauguran senderos para las políticas públicas a adoptar en ámbitos territoriales más amplios. 